\title{
Effect of action double stream nozzles on the degree of cover sprayer objects
}

\author{
Wpływ sposobu działania rozpylaczy dwustrumieniowych \\ na stopień pokrycia opryskiwanych obiektów
}

\author{
Antoni Szewczyk, Deta Łuczycka, Beata Cieniawska
}

\section{Summary}

So far, the basis for the plant protection from pests is the use of pesticides primarily as spraying application. Priorities of spraying remain invariably; striving to achieve a high quality crops, more efficient and regard to natural environment protection and human safety. One of the criteria for assessment of operation nozzles and the determinant of the quality spraying is the degree of coverage sprayer objects. The purpose of the research was to determine the effect of the mode action of selected double stream nozzles on their effects assessed on the basis the degree of coverage sprayer objects. The study compared seven double stream nozzles that differ design and, above all, setting of atomized streams. Based on the results and statistical analysis a wide variation of coverage of objects for each used nozzles was determined.

Key words: nozzle, coverage degree, spraying, comparative analysis

\section{Streszczenie}

Dotychczas podstawą ochrony upraw przed agrofagami jest stosowanie środków ochrony roślin z wykorzystaniem przede wszystkim zabiegu opryskiwania. Priorytetami opryskiwania pozostają niezmiennie: dążenie do uzyskania wysokiej jakości plonów, większej wydajności wraz z dbałością o środowisko naturalne i bezpieczeństwo ludzi. Jednym z kryteriów oceny pracy rozpylaczy i wyznacznikiem jakości zabiegu jest stopień pokrycia opryskiwanych obiektów. Celem przeprowadzonych badań było określenie wpływu sposobu działania wybranych rozpylaczy dwustrumieniowych na efekty ich działania, oceniane na podstawie stopnia pokrycia opryskiwanych obiektów. W pracy przeprowadzono ocenę porównawczą 7 rozpylaczy dwustrumieniowych różniących się cechami konstrukcyjnymi, a przede wszystkim ustawieniem rozpylonych strug. Na podstawie uzyskanych wyników i analizy statystycznej stwierdzono duże zróżnicowanie uzyskanego stopnia pokrycia opryskiwanych obiektów dla poszczególnych rozpylaczy.

Słowa kluczowe: rozpylacz, stopień pokrycia, opryskiwanie, analiza porównawcza

\author{
Uniwersytet Przyrodniczy we Wrocławiu \\ Instytut Inżynierii Rolniczej \\ Chełmońskiego 37/41, 51-630 Wrocław \\ antoni.szewczyk@up.wroc.pl; beata.cieniawska@up.wroc.pl
}




\section{Wstęp / Introduction}

Stosowanie chemicznej ochrony roślin jest obecnie warunkiem skutecznej ochrony upraw przed agrofagami oraz umożliwia uzyskanie wysokiej jakości plonu (Nieróbca i wsp. 2010). Właściwe stosowanie metody chemicznej ochrony roślin może być poniekąd gwarantem wysokiej jakości plonu i większej wydajności (Oerke i wsp. 1994; Özkan 2008; Pruszyński i wsp. 2008).

Najszybszą i najprostszą metodą oceny jakości opryskiwania jest analiza stopnia pokrycia opryskiwanych powierzchni (Koch 2005; Lipiński i wsp. 2007; Wachowiak i Kierzek 2010).

Wyniki badań otrzymuje się po poddaniu próbników - najczęściej papierków wodoczułych - komputerowej analizie obrazu (Hoffmann i Hewitt 2005; Lipiński i wsp. 2007; Szewczyk i wsp. 2011, 2012). Szeroka gama oferowanych rozpylaczy i brak obiektywnej informacji utrudnia użytkownikom opryskiwaczy w miarę optymalny wybór, stosownie do warunków pogodowych i eksploatacyjnych. Mając to na uwadze w Instytucie Inżynierii Rolniczej Uniwersytetu Przyrodniczego we Wrocławiu przeprowadzono badania pozwalające zwiększyć zakres informacji w tej dziedzinie.

Celem pracy było porównanie stopnia pokrycia opryskiwanych obiektów przy użyciu rozpylaczy dwustrumieniowych o odmiennej konstrukcji, różniących się ustawieniem rozpylonych strug podczas opryskiwania, z zachowaniem stałej dawki cieczy i prędkości opryskiwania.

\section{Materiały i metody / Materials and methods}

Badania przeprowadzono w Instytucie Inżynierii Rolniczej we Wrocławiu, w warunkach laboratoryjnych, na stanowisku badawczym imitującym zabieg opryskiwania z wykorzystaniem nośnika rozpylaczy funkcjonującego jak samodzielny samojezdny opryskiwacz. Schemat stanowiska, został przedstawiony na rysunku 1 .

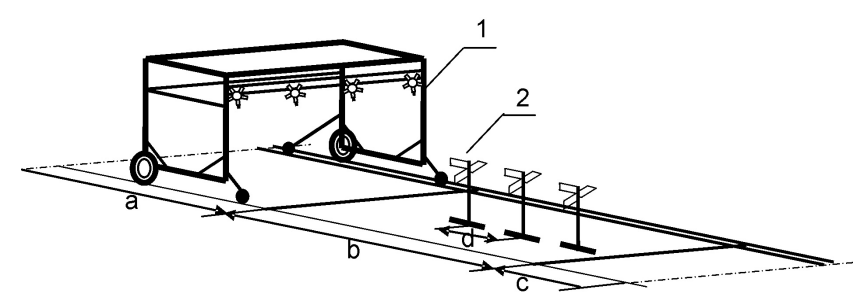

Rys. 1. Schemat stanowiska badawczego: 1 - nośnik rozpylaczy, 2 - sztuczna roślina, a - odcinek rozbiegowy, $\mathrm{b}$ - odcinek pomiarowy, c - odcinek końcowy, d odległość pomiędzy sztucznymi roślinami

Fig. 1. Schematic representation of the measurement stand for research on the coverage degree of the sprayed objects: 1 - sprayers carrier, 2 - an artificial plant, a - run line, $\mathrm{b}$ - a measurement line, $\mathrm{c}$ - ending line, $\mathrm{d}$ - distance between artificial plant
Nośnik rozpylaczy składał się z układu cieczowego, odpowiadającego za utrzymanie zadanego ciśnienia roboczego oraz układu jezdnego, umożliwiającego jego przejazd. Trasę poruszania się nośnika podzielono na trzy części - rozbiegową, pomiarową i końcową. Podczas przejazdu po odcinku rozbiegowym nośnik uzyskiwał zadaną prędkość, następnie przejeżdżał 10-metrowy odcinek pomiarowy, na którym ustawiono trzy sztuczne rośliny w 3-metrowych odstępach, dzięki czemu wykonano doświadczenia w trzech powtórzeniach i na odcinku końcowym wytracał prędkość aż do zatrzymania. Zdjęcie sztucznej rośliny użytej do badań przedstawiono na rysunku 2 .

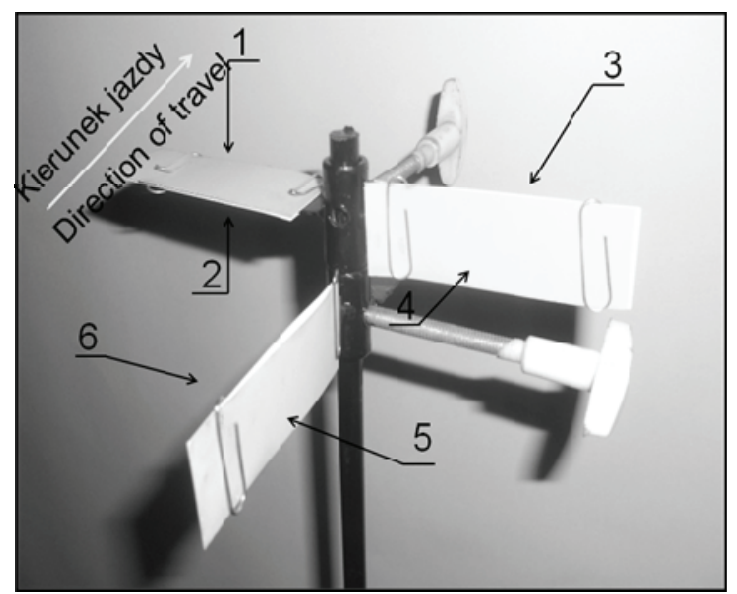

Rys. 2. Widok sztucznej rośliny $\mathrm{z}$ zaznaczonymi badanymi obiektami: 1 - poziomy górny $\left(\mathrm{A}_{\mathrm{pog}}\right), 2$ - poziomy dolny $\left(\mathrm{A}_{\mathrm{pod}}\right), 3$ - pionowy poprzeczny odjazdowy $\left(\mathrm{A}_{\mathrm{oj}}\right), 4$ - pionowy poprzeczny najazdowy $\left(\mathrm{A}_{\mathrm{nj}}\right), 5$ pionowy wzdłużny prawy $\left(\mathrm{A}_{\mathrm{bp}}\right), 6-$ pionowy wzdłużny lewy $\left(\mathrm{A}_{\mathrm{bl}}\right)$

Fig. 2. View of an artificial plant with marked researched facilities: 1 - upper level $\left(A_{p o g}\right), 2$ - lower level $\left(A_{\text {pod }}\right)$, 3 - vertical transverse leaving $\left(\mathrm{A}_{\mathrm{oj}}\right), 4$ - vertical transverse approach $\left(A_{n j}\right), 5$ - vertical longitudinal right $\left(A_{b p}\right), 6$ - vertical longitudinal left $\left(A_{b l}\right)$

Umieszczone na niej próbniki w postaci papierków wodoczułych stanowiły obiekty opryskiwane oznaczone jako: poziome oraz pionowe poprzeczne i wzdłużne. Ustaloną prędkość pracy ustawiono poprzez przyjęcie odpowiedniej wartości na przetworniku częstotliwości, który dla prędkości 2,78 m/s wynosił $30,7 \mathrm{~Hz}$.

Do badań wybrano rozpylacze, różniące się cechami konstrukcyjnymi i w konsekwencji sposobem działania. Były to rozpylacze o takim samym natężeniu wypływu cieczy, za wyjątkiem jednostrumieniowych Lo-Drift 110-015, które zamontowane w korpusie dwurozpylaczowym, sposobem pracy odpowiadały pozostałym i przy ustalonym dla wszystkich rozpylaczy ciśnieniu cieczy 0,4 MPa charakteryzowały się tym samym wydatkiem sumarycznym.

Widok zastosowanych $\mathrm{w}$ badaniach rozpylaczy przedstawiono na rysunku 3. Na rysunkach 4-10 pokazano zasadę działania poszczególnych rozpylaczy, a w tabeli 1 . ich charakterystykę. 


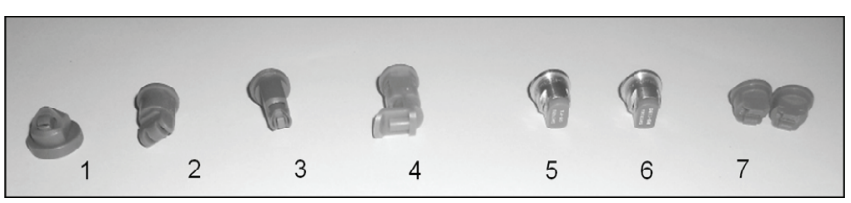

Rys. 3. Rozpylacze użyte w badaniach: 1 - HiSpeed 110-03, 2 - AITTJ 60 110-03, 3 - CVI TWIN 110-03, 4 - AI 3070-03, 5 - TJ 60 110-03, 6 - DGTJ 60 110-03, 7 Lo-Drift 110-015

Fig. 3. Nozzles used in the studies: 1 - HiSpeed 110-03, $2-$ AITTJ 60 110-03, 3 - CVI TWIN 110-03, 4 - AI 3070- 03, 5 - TJ 60 110-03, 6 - DGTJ 60 110-03, 7 Lo-Drift 110-015

Tabela 1. Charakterystyka badanych rozpylaczy Table 1. Characteristics of nozzle

\begin{tabular}{l|l|c|c|c}
\hline \multirow{2}{*}{$\begin{array}{c}\text { Lp. } \\
\text { No. }\end{array}$} & \multicolumn{1}{|c|}{$\begin{array}{c}\text { Rozpylacz } \\
\text { Nozzle }\end{array}$} & \multicolumn{2}{|c|}{$\begin{array}{c}\text { Ustawienie } \\
\text { rozpylonej strugi } \\
\text { Setting stream } \\
\text { spray }\end{array}$} & $\begin{array}{c}\text { Typ } \\
\text { rozpylacza } \\
\text { Type } \\
\text { of nozzle }\end{array}$ \\
\cline { 3 - 4 } 1. & HiSpeed 110-03 & $\begin{array}{c}\text { przednia } \\
\text { front }\end{array}$ & $\begin{array}{c}\text { tylna } \\
\text { back }\end{array}$ & \\
\hline 2. & AITTJ 60 110-03 & $30^{\circ}$ & $10^{\circ}$ & E \\
\hline 3. & CVI TWIN 110-03 & $30^{\circ}$ & $30^{\circ}$ & E \\
\hline 4. & AI 3070-03 & $30^{\circ}$ & $70^{\circ}$ & E \\
\hline 5. & TJ 60 110-03 & $30^{\circ}$ & $30^{\circ}$ & $\mathrm{S}$ \\
\hline 6. & DGTJ 60 110-03 & $30^{\circ}$ & $30^{\circ}$ & $\mathrm{A}$ \\
\hline 7. & Lo-Drift 110-015 & $30^{\circ}$ & $30^{\circ}$ & $\mathrm{A}$ \\
\hline
\end{tabular}

E - eżektorowy - air-injector, A - antyznoszeniowy - antidrift, S standardowy - standard

W celu statystycznego opracowania zastosowano jednoczynnikową analizę wariancji oraz test Tukeya.

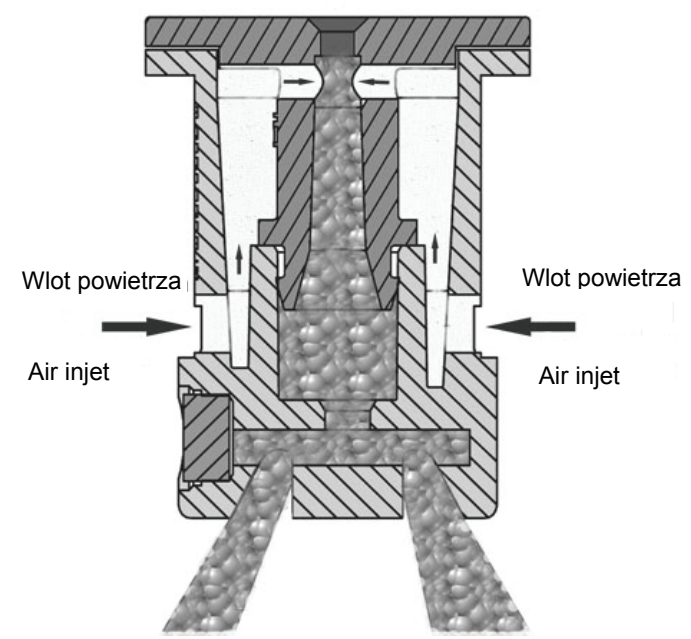

Rys. 4. Rozpylacz AITTJ 60

Fig. 4. Nozzle AITTJ 60

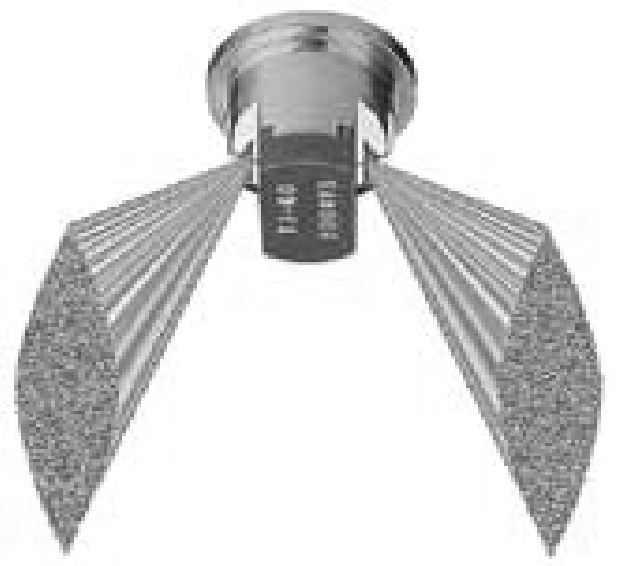

Rys. 5. Rozpylacz TJ 60

Fig. 5. Nozzle TJ 60

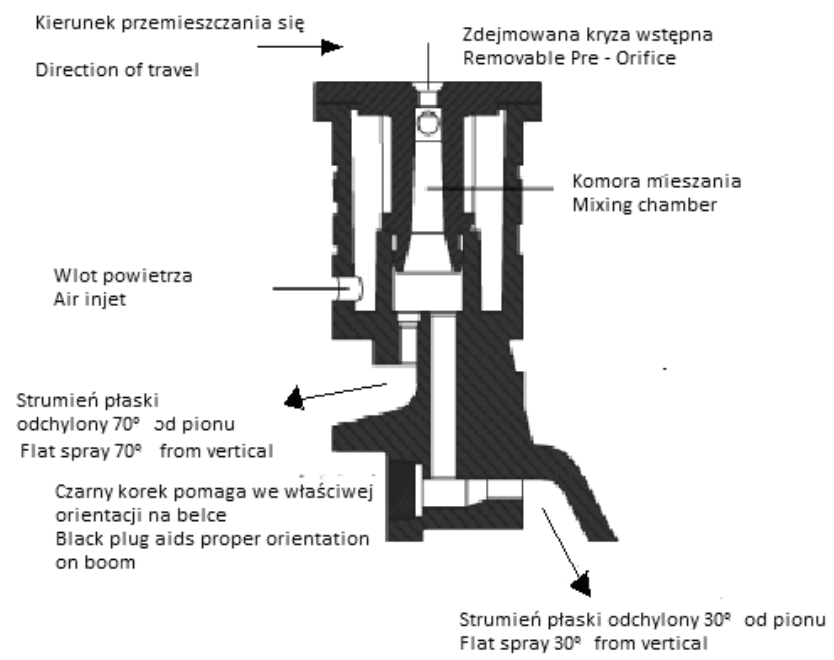

Rys. 6. Rozpylacz AI 3070

Fig. 6. Nozzle AI 3070

Źródło: - Source:

http://www.agrojet.pl.
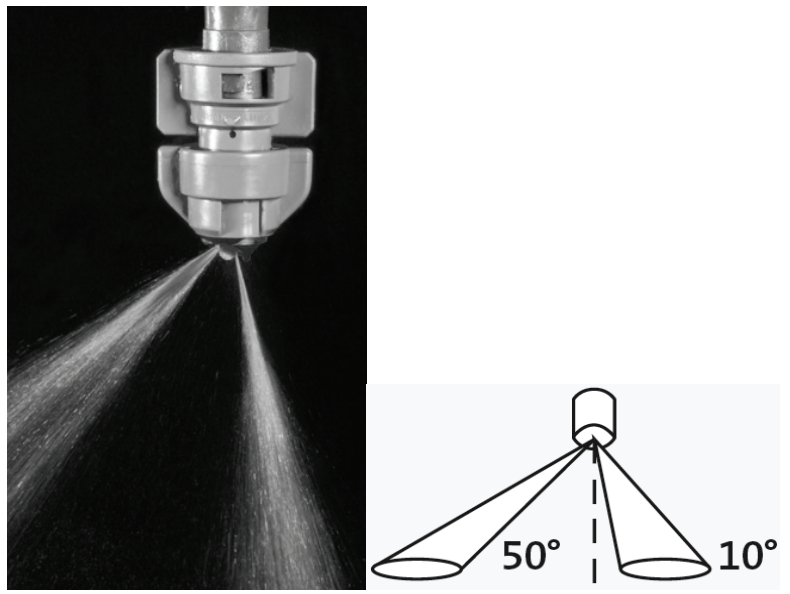

Rys. 7. Rozpylacz HiSpeed

Fig. 7. Nozzle HiSpeed http://www.agrotop.com 


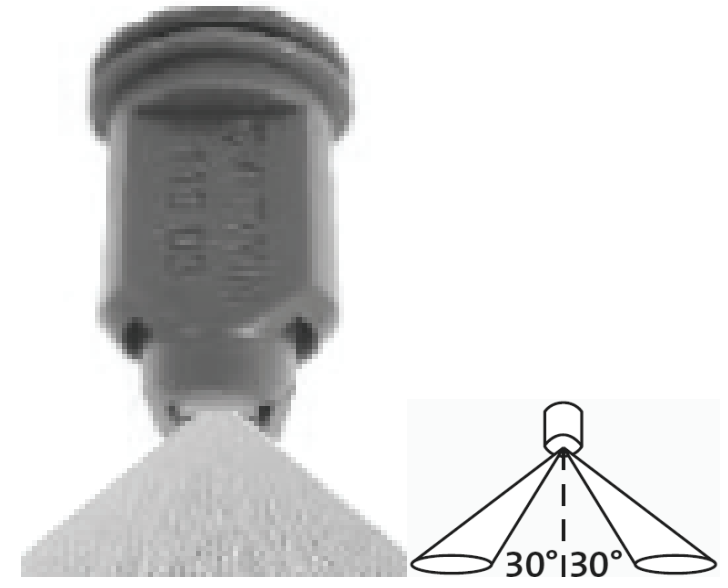

Rys. 8. Rozpylacz CVI TWIN

Fig. 8. Nozzle CVI TWIN

http://rubena.home.pl

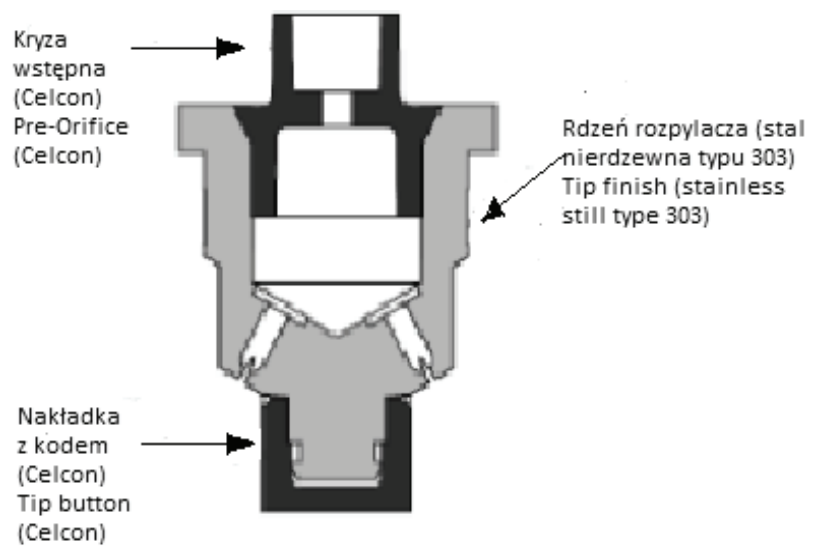

Rys. 9. Rozpylacz DGTJ 60

Fig. 9. Nozzle DGTJ 60

http://www.arajspray.ovh.org

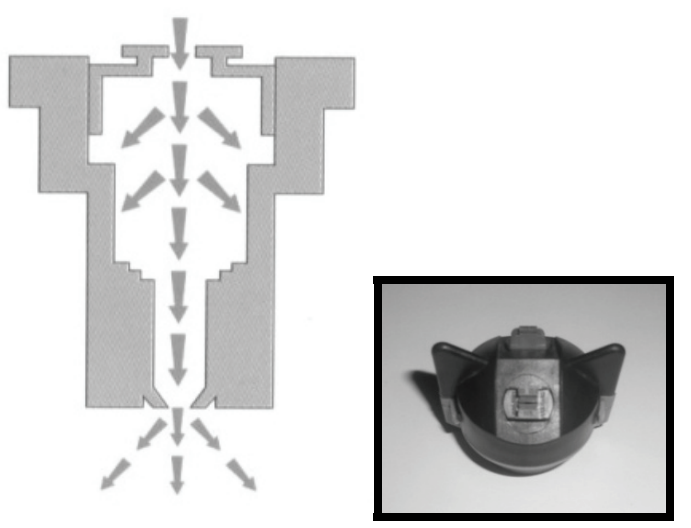

Rys. 10. Rozpylacz Lo-Drift i korpus dwurozpylaczowy Fig. 10. Nozzle Lo-Drift and corp two nozzles http://www.agrojet.pl

\section{Wyniki i dyskusja / Results and discussion}

Wyniki badań zaprezentowano na wykresach słupkowych, przedstawionych na rysunkach $11-14$. Na rysun- ku 11. pokazano wyniki badań stopnia pokrycia obiektów poziomych górnych. Przy porównaniu rozpylaczy widać, że najniższe wartości stopnia pokrycia badanych powierzchni zanotowano dla tych rozpylaczy, które charakteryzowały się asymetrycznym kątem rozpylenia. Najwyższą wartość natomiast zaobserwowano dla rozpylaczy antyznoszeniowych Lo-Drift 110-015, zamontowanych w korpusie dwurozpylaczowym, tak by strumienie były ustawione symetrycznie względem siebie.

Na rysunku 12. przedstawiono wyniki badań obiektów pionowych poprzecznych - najazdowych i odjazdowych. Najwyższą wartością stopnia pokrycia obiektów pionowych poprzecznych zarówno najazdowych, jak i odjazdowych charakteryzowały się podobnie jak poprzednio rozpylacze Lo-Drift 110-015. Natomiast najniższą wartości pokrycia obiektów najazdowych zanotowano dla rozpylaczy DGTJ 60 110-03, a dla obiektów pionowych odjazdowych $\mathrm{z}$ zastosowaniem rozpylacza AI 3070-03. Największe różnice pomiędzy wartością stopnia pokrycia poszczególnych obiektów zarejestrowano dla rozpylaczy AI 3070-03 oraz CVI TWIN 110-03. Najmniejsze pokrycie cieczą stwierdzono dla rozpylaczy HiSpeed 110-03 oraz TJ 60 110-03. Ponadto w przypadku tych ostatnich rozpylaczy zaobserwowano najmniejsze różnice stopnia pokrycia obiektów najazdowych i odjazdowych.

$\mathrm{Na}$ rysunku 13. przedstawiono wyniki badań obiektów pionowych wzdłużnych prawych i lewych.

W grupie rozpylaczy dwustrumieniowych najwyższą wartość pokrycia uzyskano przy opryskiwaniu rozpylaczem o asymetrycznym kącie rozpylenia - HiSpeed110-03, a najniższą - DGTJ 60 110-03.

W przypadku opryskiwania obiektów pionowych wzdłużnych największą różnicę pomiędzy badanymi obiektami zanotowano dla rozpylaczy AI 3070-03 $13,3 \%$ oraz CVI TWIN $110-03-6,42 \%$, a najniższe różnice wystąpiły dla rozpylacza HiSpeed 110-03 $0,62 \%$. W przypadku rozpylacza TJ $60110-03$ nie stwierdzono żadnych różnic $\mathrm{W}$ stopniu pokrycia dla lewej i prawej strony.

$\mathrm{Na}$ rysunku 14. przedstawiono wyniki średniego stopnia pokrycia opryskiwanych obiektów. Najmniejszą wartość średniego stopnia pokrycia odnotowano dla rozpylaczy AI 3070-03 (9,92\%), a największą (21,25\%) dla rozpylaczy Lo-Drift 110-015. Na wykresie widać, że mimo dużych różnic ustawienia rozpylonych strug rozpylacze eżektorowe - HiSpeed 110-03 oraz CVI TWIN 110-03 charakteryzowały się zbliżonym średnim stopniem pokrycia badanych obiektów.

Jak wspomniano w metodyce w celu statystycznego opracowania wyników badań przeprowadzono jednoczynnikową analizę wariancji (tab. 2). Na jej podstawie stwierdzono, że typ rozpylacza ma istotny wpływ (na poziomie istotności $\alpha=0,05$ ) na stopień pokrycia opryskiwanych obiektów. Na podstawie przeprowadzonego testu Tukeya stwierdzono, że istotne różnice wystąpiły jedynie pomiędzy rozpylaczami CVI TWIN 110-03 i Lo-Drift 110-015 oraz AI 3070-03 i Lo-Drift 110-15. 


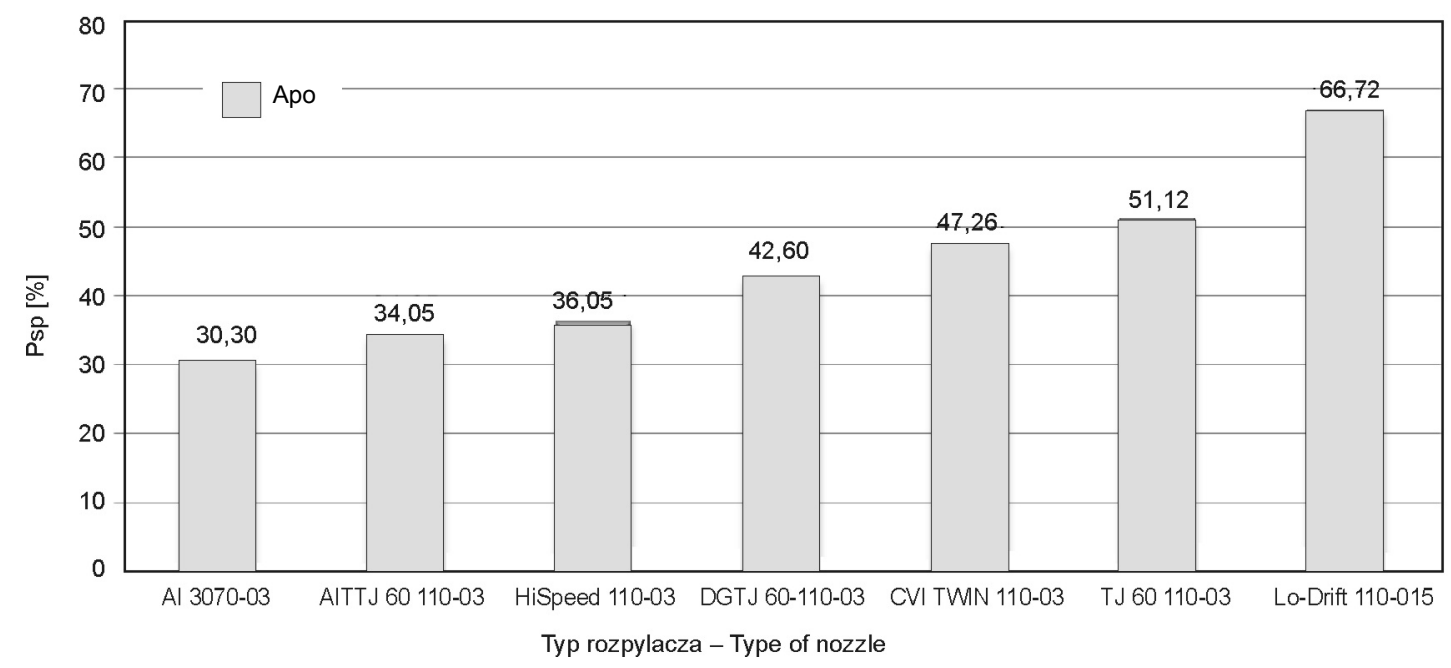

Rys. 11. Stopień pokrycia $\left(\mathrm{P}_{\mathrm{sp}}\right)$ obiektów poziomych górnych $\left(\mathrm{A}_{\mathrm{po}}\right)$ dla wybranych typów rozpylaczy

Fig. 11. Coverage degree $\left(\mathrm{P}_{\mathrm{sp}}\right)$ of upper horizontal objects $\left(\mathrm{A}_{\mathrm{po}}\right)$ for select type nozzles

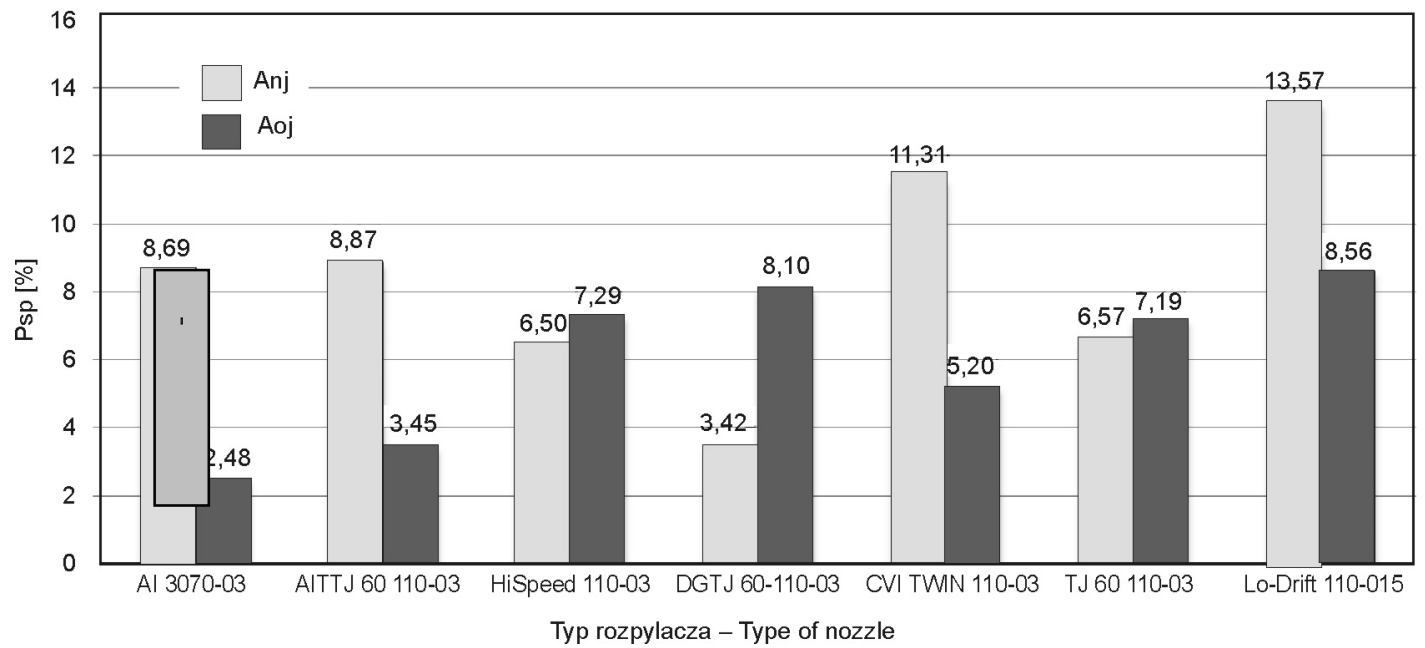

Rys. 12. Stopień pokrycia $\left(\mathrm{P}_{\mathrm{sp}}\right)$ opryskiwanych obiektów pionowych poprzecznych najazdowych $\left(\mathrm{A}_{\mathrm{nj}}\right)$ i odjazdowych $\left(\mathrm{A}_{\mathrm{oj}}\right)$ dla wybranych typów rozpylaczy

Fig. 12. Coverage degree $\left(P_{\mathrm{sp}}\right)$ of transverse vertical objects approach $\left(\mathrm{A}_{\mathrm{nj}}\right)$ and leaving $\left(\mathrm{A}_{\mathrm{oj}}\right)$ for select type nozzles

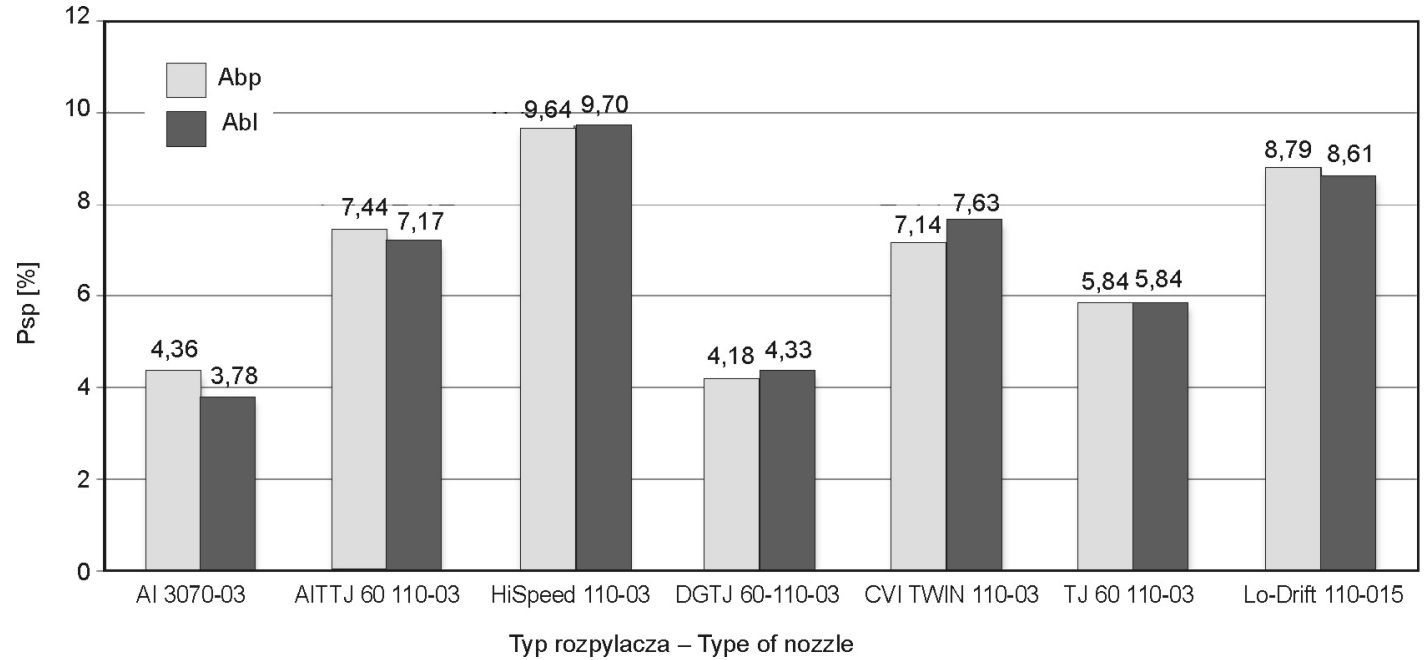

Rys. 13. Stopień pokrycia $\left(\mathrm{P}_{\mathrm{sp}}\right)$ opryskiwanych obiektów pionowych wzdłużnych prawych $\left(\mathrm{A}_{\mathrm{bp}}\right)$ i lewych $\left(\mathrm{A}_{\mathrm{bl}}\right)$ wybranych typów rozpylaczy

Fig. 13. Coverage degree $\left(\mathrm{P}_{\mathrm{sp}}\right)$ of longitudinal vertical objects right $\left(\mathrm{A}_{\mathrm{bp}}\right)$ and left $\left(\mathrm{A}_{\mathrm{bl}}\right)$ for select type nozzles 


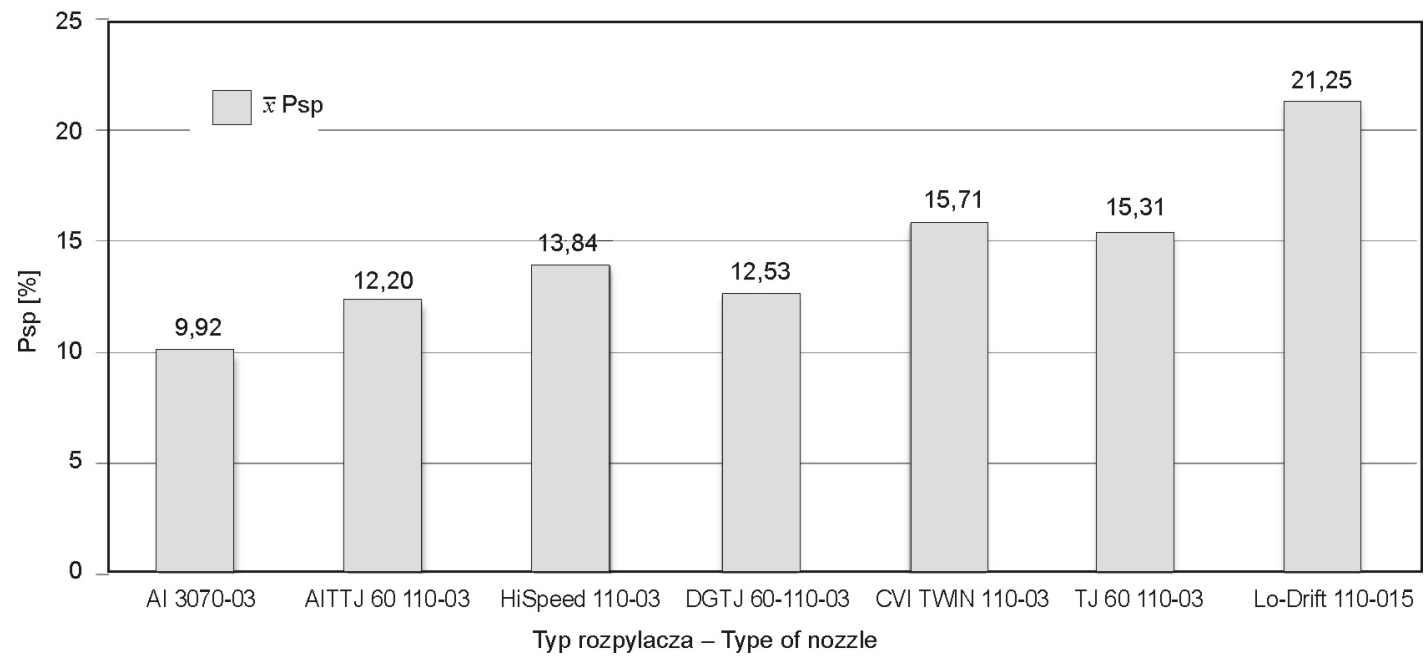

Rys. 14. Średni stopień pokrycia $\left(\mathrm{P}_{\mathrm{sp}}\right)$ opryskiwanych obiektów

Fig. 14. Medium coverage $\left(\mathrm{P}_{\mathrm{sp}}\right)$ degree objects

Tabela 2. Wyniki jednoczynnikowej analizy wariancji

Table 2. Results of one-factorial variation analysis

\begin{tabular}{l|c|c|c}
\hline & $\begin{array}{c}\text { Stopnie swobody } \\
\text { Degrees of freedom }\end{array}$ & $\begin{array}{c}\text { Wartość funkcji testowej } \mathrm{F} \\
\text { Value of function test } \mathrm{F}\end{array}$ & $\begin{array}{c}\text { Wartość poziomu prawdopodobieństwa } \mathrm{p} \\
\text { Value of level of probability } \mathrm{p}\end{array}$ \\
\hline $\begin{array}{l}\text { Wyraz wolny } \\
\text { Free term }\end{array}$ & 1 & 852,3069 & 0,0000 \\
\hline $\begin{array}{l}\text { Rozpylacz } \\
\text { Nozzle }\end{array}$ & 6 & 7,6589 & 0,0000 \\
\hline
\end{tabular}

Zdaniem autorów godny podkreślenia jest fakt, że analiza wyników badań wykazała brak śladów pokrycia rozpylaną cieczą obiektów poziomych dolnych, co jest zgodne z wcześniejszymi badaniami z zastosowaniem rozpylaczy dwustrumieniowych (Szewczyk i wsp. 2012). Trzeba również podkreślić, że prezentowane w niniejszej pracy wyniki uzyskano w warunkach laboratoryjnych, gdzie opryskiwane obiekty utrzymują podczas eksperymentu stałe położenie. Badania prowadzone w warunkach polowych moga, w tym zakresie, dać odmienne rezultaty. Jak donoszą Kierzek i Wachowiak (2009) przy opryskiwaniu ziemniaków w warunkach doświadczenia poletkowego uzyskano pokrycie spodnich stron blaszek liściowych, a stopień pokrycia zwiększył się po zastosowaniu adiuwantu.

Przedstawione w pracy wyniki badań odpowiadają także na zapotrzebowanie praktyki ochroniarskiej, gdyż jak twierdzi wielu autorów, skuteczność zabiegu opryskiwania zależy od poziomu oraz równomierności naniesienia cieczy użytkowej, równomierności rozkładu poprzecznego oraz stopnia pokrycia opryskiwanych powierzchni. O tym, w dużej mierze, decydują zastosowane rozpylacze (Zhu i wsp. 2006; Godyń i wsp. 2008) i dlatego wybór odpowiedniego rodzaju rozpylacza jest ważnym aspektem zarówno w ochronie upraw polowych, jak i sadowniczych (Guler i wsp. 2007; Kierzek 2007; Tadel 2007; Kierzek i Wachowiak 2009). Kierzek (2008) w analizie wielu no- wych rozpylaczy, jakie ukazały się na rynku, stwierdził że przez odpowiedni dobór rozpylaczy można uzyskać dokładną aplikację środka chemicznego, a przez to wysoką skuteczność biologiczną zabiegu ochroniarskiego.

\section{Wnioski / Conclusions}

1. Analiza wyników badań, poparta analizą statystyczną, wykazała, że wystąpiły istotne różnice w stopniu pokrycia opryskiwanych obiektów wynikające $\mathrm{z}$ różnic konstrukcyjnych i sposobu działania badanych rozpylaczy.

2. Z analizy uzyskanych wyników wynika, że zdecydowane najlepsze pokrycie rozpylaną cieczą wystąpiło przy stosowaniu rozpylaczy Lo-Drift 110-015 zamontowanych w korpusie dwurozpylaczowym i to w przypadku wszystkich opryskiwanych obiektów. Stwierdzenie to potwierdzone zostało również średnim stopniem pokrycia zanotowanym dla tego rozpylacza.

3. Na podstawie uzyskanego podczas badań stopnia pokrycia poszczególnych opryskiwanych obiektów i obliczonego na tej podstawie średniego stopnia pokrycia można stwierdzić, że wśród typowych rozpylaczy dwustrumieniowych eżektorowych najlepsze wyniki zanotowano dla rozpylacza CVI TWIN 110-03. 


\section{Literatura / References}

Godyń A., Hołownicki R., Doruchowski G. 2008. Ocena rozkładu cieczy opryskowej w sadzie jabłoniowym wykonana za pomocą papieru wodnoczułego. Inż. Rol. 4 (102): 299-305.

Guler H., Zhu H., Özkan H.E., Derksen R.C., Yu Y., Krause C.R. 2007. Spray characteristics and drift reduction potential with air induction and conventional flat-fan nozzles. Transactions of the ASABE 50 (3): 745-754.

Hoffmann W.C., Hewitt A.J. 2005. Comparison of three imaging systems for water-sensitive papers. Appl. Eng. Agric. 21 (6): $961-964$. http://rubena.home.pl

http://www.agrojet.pl

http://www.agrotop.com

http://www.arajspray.ovh.org

Kierzek R. 2007. Skuteczna ochrona roślin [cz. II]. Dobór rozpylaczy do zabiegów polowych. Ochrona Roślin 1 (52): 32-35.

Kierzek R. 2008. Wiele rozpylaczy, jeden oprysk. Top Agrar 7-8: 118-121.

Kierzek R., Wachowiak M. 2009. Wpływ nowych typów rozpylaczy na jakość pokrycia roślin ziemniaków cieczą użytkową. [Effect of new spray nozzles on potato leaf coverage with working liquid]. Prog. Plant Prot./Post. Ochr. Roślin 49 (3): 1145-1149.

Koch H. 2005. Describing the transition zone between sprayed and unsprayed area. Annu. Rev. Agric. Engin. 4 (1): 371-377.

Lipiński A., Choszcz D., Konopka S. 2007. Ocena rozpylaczy do oprysku ziemniaków w aspekcie równomierności pokrycia roślin cieczą. Inż. Rol. 9 (97): 135-141.

Nieróbca A., Zaliwski A., Horoszkiewicz-Janka J. 2010. Rozwój internetowego systemu wspomagania decyzji w ochronie zbóż. Inż. Rol. 7 (125): 167-173.

Oerke E.C., Dehne W., Schönbeck F., Weber A. 1994. Crop Production and Crop Protection: Estimated Losses in Major Food and Cash Crops. Elsevier Science, Amsterdam, 808 pp.

Özkan H. E. 2008. Technological solution to problems associated with application of pesticides J. Agric. Machines Sci. 4 (2): $193-198$.

Pruszyński S., Mrówczyński M., Pruszyński G. 2008. Ochrona roślin w integrowanej technologii produkcji rolniczej. Probl. Inż. Rol. 1: $87-98$.

Szewczyk A., Łuczycka D., Cieniawska B., Rojek G. 2012. Porównanie stopnia pokrycia obiektów opryskiwanych wybranymi rozpylaczami eżektorowymi - jedno i dwustrumieniowym. Inż. Rol. 2 (136): 325-334.

Szewczyk A., Łuczycka D., Lejman K. 2011. Wpływ parametrów opryskiwania wybranym rozpylaczem dwustrumieniowym na stopień pokrycia opryskiwanych obiektów. Inż. Rol. 4 (129): 265-271.

Tadel E. 2007. Technika ochrony polowych upraw wysokich ze szczególnym uwzględnieniem kukurydzy. s. 100-106. 7. Ogólnopolska Konf. Racjonalna Technika Ochrony Roślin. Poznań, 2-3.10.2007, 161 ss.

Wachowiak M., Kierzek R. 2010. Tendencje w rozwoju techniki ochrony roślin - wybrane zagadnienia. [Progress in plant protection techniques - selected issues]. Prog. Plant Prot./Post. Ochr. Roślin 50 (4): 1661-1670.

Zhu H., Derksen R.C., Guler H., Krause C.R., Özkan H.E. 2006. Foliar deposition and off-target loss with different spray techniques in nursery applications. Transactions of the ASABE 49 (2): 325-333. 